\title{
Evaluation of Different Rotary Devices on Bone Repair in Rabbits
}

\author{
Paulo Domingos RIBEIRO JUNIOR ${ }^{1}$ \\ Christiane Vespasiano BARLETO ${ }^{1}$ \\ Daniel Araki RIBEIRO ${ }^{2}$ \\ Mariza Akemi MATSUMOTO ${ }^{1}$ \\ ${ }^{1}$ Department of Oral Surgery, Sacred Heart University, Bauru, SP, Brazil \\ ${ }^{2}$ Department of Health Sciences, Federal University of São Paulo,UNIFESP, Santos, SP, Brazil
}

\begin{abstract}
In oral surgery, the quality of bone repair may be influenced by several factors that can increase the morbidity of the procedure. The type of equipment used for ostectomy can directly affect bone healing. The aim of this study was to evaluate bone repair of mandible bone defects prepared in rabbits using three different rotary devices. Fifteen New Zealand rabbits were randomly assigned to 3 groups $(n=5)$ according to type of rotary device used to create bone defects: I - pneumatic low-speed rotation engine, II - pneumatic high-speed rotation engine, and III - electric low-speed rotation engine. The anatomic pieces were surgically obtained after 2, 7 and 30 days and submitted to histological and morphometric analysis. The morphometric results were expressed as the total area of bone remodeling matrix using an image analysis system. Increases in the bone remodeling matrix were noticed with time along the course of the experiment. No statistically significant differences $(p>0.05)$ were observed among the groups at the three sacrificing time points considering the total area of bone mineralized matrix, although the histological analysis showed a slightly advanced bone repair in group III compared to the other two groups. The findings of the present study suggest that the type of rotary device used in oral and maxillofacial surgery does not interfere with the bone repair process.
\end{abstract}

Key Words: bone repair, rotary instruments, oral surgery.

\section{INTRODUCTION}

Rigid technical principles are required during surgical procedures in order to achieve an efficient treatment with low morbidity. In oral and maxillofacial surgery, ostectomy is a common procedure used in minor and major interventions, such as facial traumas and orthognatics $(1,2)$.

Initially, osteotomies were performed using chisels and hammers. Later, osteotomies benefited from the introduction of rotary devices to oral surgery, becoming less time-consuming procedures with increased comfort to the patient and subsequent better technical and biological outcomes due to a more accurate cut definition (3-5). The choice for the type of rotary equipment to be used depends on the surgical procedure, anatomical site and bone characteristics. Bone density as well as the pressure supported by the tissue increases local temperature, hindering wound healing (6). Herein, rotary instruments must be used under copious irrigation (7-9) during and after osteotomy because bone injury can delay bone repair (10).

High-speed devices can reach 330,000 rpm increasing the temperature of the bur and causing some difficulty in hand controlling when compared to the low-speed devices. Moreover, the centricity of rotary devices and burs must be observed and controlled, and patients may benefit from studies that investigate the effects of different kinds of osteotomy on bone healing. Electric devices provide a uniform osteotomy, with a more proper cut surface when compared to pneumatic equipments (3).

Therefore, this study investigated the pattern of bone repair in rabbit mandible defects prepared 
with three types of different rotary devices.

\section{MATERIAL AND METHODS}

This experimental protocol was approved by the Ethics in Animal Research Committee of the School of Dentistry of the Sacred Heart University, Brazil.

Fifteen adult New Zealand male rabbits, weighing 4-5 kg were randomly assigned to 3 groups $(n=5)$ according to rotary the device used: I - pneumatic lowspeed rotation (Kavo, Joinvile, SC, Brazil; maximum of 2,000 rpm); II - pneumatic high-speed rotation (Kavo; maximum of 330,000 rpm); and III - electric low-speed rotation (K9; Kavo; maximum of 25,000 rpm). Shortly after trichotomy, two incisions were prepared bilaterally in the submandibular region, so that basal mandibular bone could be visualized. The ostectomies (total of 3 per animal, one for each device) were performed with 2.3mm diameter spherical burs (Komet; Basseler, São Paulo, SP, Brazil) attached to each of the 3 rotary devices mentioned above. One bur was used per procedure. All bone defects were prepared under copious saline irrigation and the distance between the osteotomies was approximately $3.0 \mathrm{~mm}$.

After being created, the bone defects were cleaned with $10 \mathrm{~mL}$ of saline, separately, along with continuous aspiration, keeping a standardized distance of the syringe for all cavities. The soft tissue was closed with 3-0 polyglactin 910 suture (Vycril, Johnson \& Johnson, São José dos Campos, SP, Brazil). All surgical procedures were performed under general anesthesia with ketamine (Francotar, Virbac, São Paulo, SP, Brazil; 0.30 mL/kg body weight).

After 2, 7 and 30 days, the animals were sacrificed by anesthetic overdose and the mandibles were removed along with the covering soft tissue. The mandibles of all rabbits were longitudinally cut into halves for histological examination. Tissues were fixed in $10 \%$ buffered formalin, demineralized with Morse solution, embedded in paraffin blocks and stained with hematoxylin and eosin (HE) and Alcian Ponceau.

To confirm the interpretation of the histological analysis in the mandibular bone defects, a computerbased programmable image-analysis system for Windows (KS-300, Carl Zeiss, Germany) was used to perform a morphometric assessment of the Alcian Ponceau-stained sections. Namely, three representative areas from the mandible defects of each sample were analyzed by systematic sampling at $250 \mathrm{X}$ magnification. The total area of bone remodeling was measured and expressed in millimeter square $\left(\mathrm{mm}^{2}\right)$. All components other than the bone remodeling matrix were excluded from analysis. When all fields of each mandible defect were analyzed, the total area was calculated. The results were presented as the mean total area for each specimen analyzed in each group.

Statistical analysis was performed by one-way ANOVA using SPSS software (version 1.0; SPSS Inc., Chicago, IL, USA). A $p$ value $<0.05$ was considered statistically significant.

\section{RESULTS}

\section{Histological Analysis}

Two Days - Two days after surgery, no remarkable differences were noticed among the groups. In general, all specimens presented bone cavity filled by blood clot, characterized by numerous red blood cells and fibrin network (Figs. 1A-C).

Seven Days - After 1 week, all groups showed newly formed intramembranous bone arising from the cavity walls. Osteogenesis was slightly more intense in Group I (Fig. 2A) compared to Groups II and III (Figs. 2B, C). Osteoconduction was evident in the periphery. In the central areas, blood clot and granulation tissue were more evident in Group III (Fig. 2C).

Thirty days - At this period, viable trabeculae were noted in all groups, with the presence of lamellar areas that indicated the beginning of bone remodeling. Osteoclasts were visualized on the surface of the bone trabeculae. In most specimens, the bone defects were filled by remodeling bone tissue, which made it difficult to accurately delimit the cavity walls (Figs. 3A-C).

\section{Morphometric Analysis}

No bone remodeling matrix was observed at 2 days after surgery in either of the groups. A significant increase of approximately $75 \%(\mathrm{p}<0.05)$ in the mean total area of the bone remodeling matrix was found between 7 and 30 days after surgery in all groups.

On the other hand, the mean total area of bone remodeling matrix did not demonstrate significant changes among the groups $(\mathrm{p}>0.05)$ at the 3 sacrificing time points. These results are summarized in Table 1. 

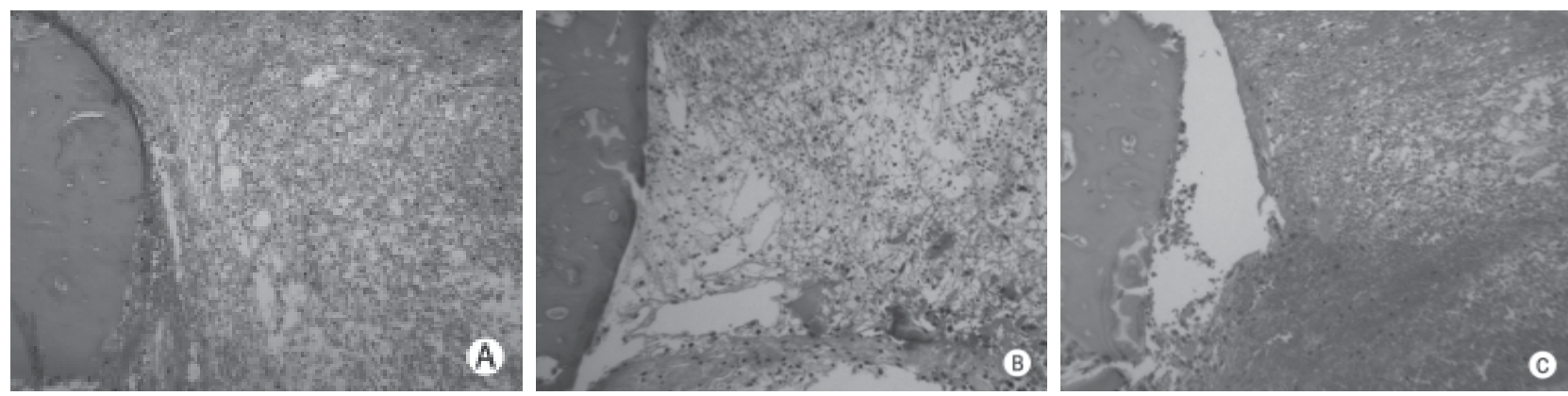

Figure 1. Two days. Images of group I (A), group II (B) and group III (C) showing similar microscopic features, with bone defects filled with blood clot (HE; original magnification: $\times 5)$.
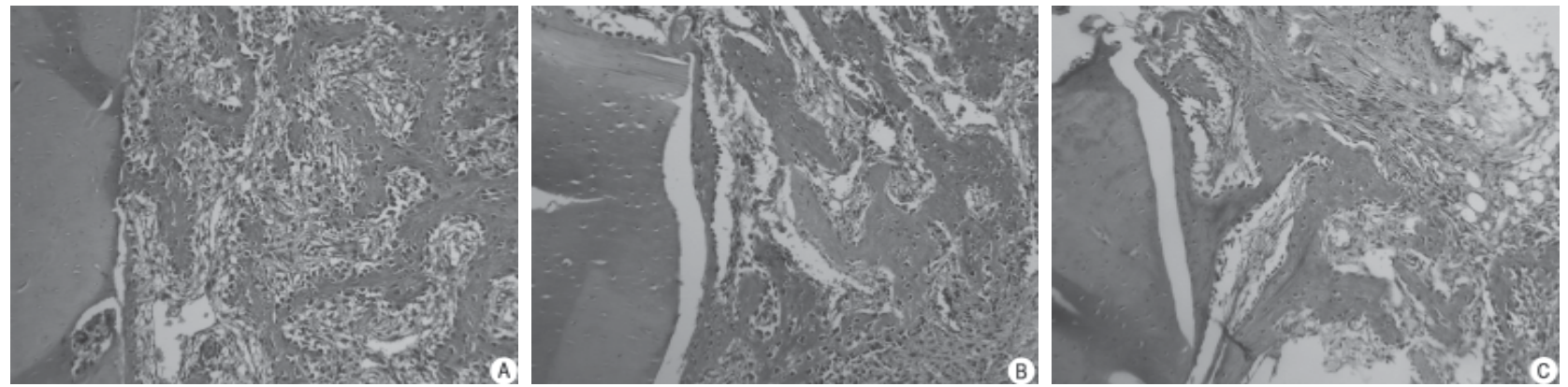

Figure 2. Seven days. Woven bone can be noted inside the bone cavities. Images A and B show intense osteogenesis in groups I and II. The presence of granulation tissue was more evident in group III (HE; original magnification: $\times 5$ ).
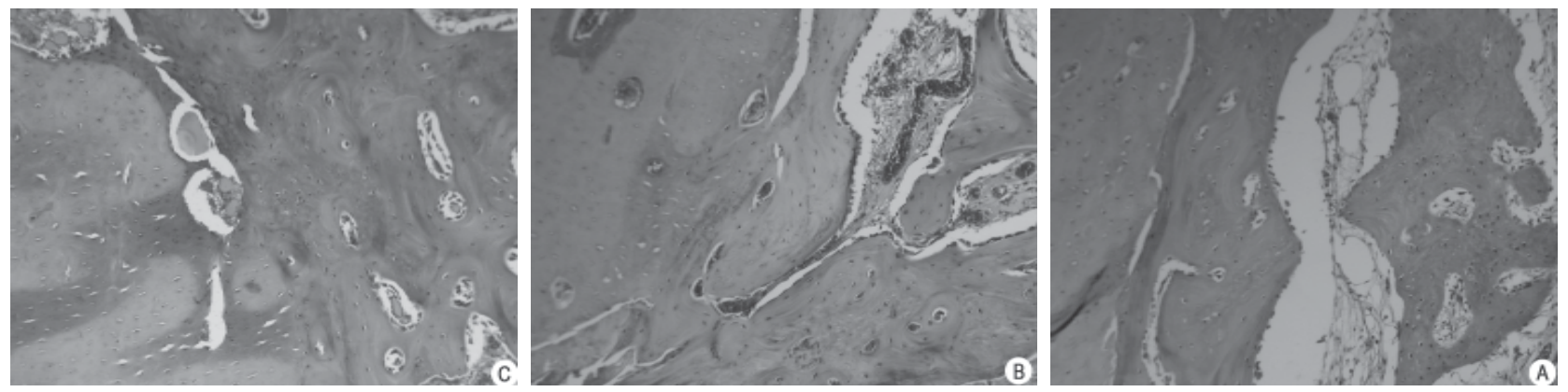

Figure 3. Thirty days. Images of group I (A), group II (B) and group III (C) showing remodeling bone filling the cavities, making it difficult to visualize the walls of the bone defects (HE; original magnification: $\times 5$ ).

Table 1. Means in $\mathrm{mm}^{2}( \pm \mathrm{SD})$ of the total area of the bone remodeling matrix at the different sacrificing time points.

\begin{tabular}{lccc}
\hline Groups & \multicolumn{3}{c}{ Day of sacrifice } \\
\cline { 2 - 4 } & 2nd & 7 th & 30th \\
\hline I $(n=5)$ & 0 & $146.42 \pm 27.41 \mathrm{a}$ & $253.87 \pm 24.52 \mathrm{~b}$ \\
II $(\mathrm{n}=5)$ & 0 & $128.71 \pm 25.23 \mathrm{a}$ & $244.00 \pm 35.72 \mathrm{~b}$ \\
III $(\mathrm{n}=5)$ & 0 & $132.84 \pm 40.38 \mathrm{a}$ & $250.26 \pm 27.20 \mathrm{~b}$ \\
\hline
\end{tabular}

Different letters indicate statistically significant difference at 5\%.

\section{DISCUSSION}

Among the tested rotary devices, it was observed that the electric equipment permitted a better manual control of the osteotomy, possibly due to the smooth rotation and practically no trembling. The pneumatic devices caused more trembling. The greater difficulty in preparing the cavities was noted using the pneumatic high-speed rotary device, even with irrigation, because this type of equipment leads the air pass to the area that is being osteotomized. Because of that, it was frequent 
to see bone debris coming from the bone walls, which could interfere in bone repair, as previous reported (11).

Cooling of the osteotomized area during and after the procedure is an important step that contributes to a lower local morbidity (7-9). In the present study, continuous and copious saline irrigation was instituted at a distance approximately 5-8 $\mathrm{cm}$ of the bone surface. It is known that pressure caused by the devices as well as the size of the osteotomized area can increase local bone temperature (9). In order to control this condition, all bone defects were prepared by the same operator with a minimum of pressure on bone surface, and maintaining a cavity size that did not exceed the diameter of the bur.

A new bur was used for each ostectomy, as were provided by the supplier. It is known that the use of instruments with adequate conditions contribute to a better tissue healing (6).

The histological analysis showed that after $48 \mathrm{~h}$ (first sacrifice time point) the bone defects in the three groups were filled by blood clot. The only difference was noted in group II, in which small remaining nonviable bone fragments could be seen in some specimens. In the following periods, bone repair process occurred with no intercurrences. Although the statistical analysis showed no significant differences between the groups with respect to the area of mineralized bone matrix observed at the 7- and 30-day time points (Table 1), some histological aspects of bone remodeling were more easily observed in group III in the last experimental period.

The favorable histological results observed in group III are probably due to the better manual control provided by the electric low-speed rotation, which yields a more precise bur centricity and specially a low tissue pressure, together with an adequate cooling. These results are consistent with the clinical experience of oral surgeons and implantologists who report a better control of bone tissue removal when using electric lowspeed equipments (6).

In summary, in the present study, the histological and morphometric analyses in mandible bone defects demonstrated that the type of rotary device did not interfere with the bone repair process. These findings are clinically important and should be addressed in the planning of surgical procedures involving bone tissue. When considering bone repair, some other environmental and systemic factors should also be taken into account, as extensively discussed in literature.

\section{RESUMO}

A ostectomia é uma manobra cirúrgica fundamental que pode afetar a reparação tecidual de modo a aumentar a morbidade do procedimento. O tipo de equipamento e/ou instrumental utilizado para a ostectomia pode influenciar diretamente no reparo ósseo. O objetivo deste trabalho foi analisar o processo de reparação óssea em defeitos realizados em mandíbula de coelho com três diferentes equipamentos. Quinze coelhos foram aleatoriamente divididos em 3 grupos $(n=5)$ de acordo com o equipamento usado para preparacão de 3 cavidades ósseas com brocas padronizadas: I) motor de baixa rotação pneumático, II) motor de alta rotação pneumático e III) motor de baixa rotação elétrico, todos com refrigeração constante. Após os períodos experimentais de 2, 7e 30 dias, as peças anatômicas foram removidas e submetidas a análises microscópica e histomorfométrica. Não houve diferença estatisticamente significante $(p>0,05)$ entre os grupos nos 3 períodos experimentais, considerando-se a área total de matriz óssea mineralizada, embora a análise microscópica tenha revelado uma tendência a um processo de reparação óssea um pouco mais adiantado no grupo III, quando comparado aos demais grupos. Os resultados deste estudo sugerem que o tipo de equipamento rotatório utilizado em cirurgia bucomaxilofacial não interfere no reparo ósseo.

\section{ACKNOWLEDGEMENTS}

The authors acknowledge financial support from the Brazilian National Council of Research (CNPq).

\section{REFERENCES}

1. Backer S, Dalrymple D, Betts N. Concepts and techniques of rigid fixation. In: Oral and maxillofacial trauma. Fonseca RJ, Walker RV (Editors). 2nd ed. Philadelphia: W.B. Saunders, 1997:1274-1317.

2. Tucker MR. Correction of dentofacial deformities. In: Peterson LJ, Ellis E, Hupp JR, Tucker, MR (Editors). Contemporary Oral and Maxillofacial Surgery. St Louis: Mosby, 2000:600-638.

3. Costich ER, Youngblood PJ, Walden JM. A study of the effects of high-speed rotary instruments on bone repair in dogs. Oral Surg Oral Med Oral Pathol 1964;17:563-571.

4. Horton JE, Tarpley TM, Wood LD. The healing of surgical defects in alveolar bone produced with ultrasonic defects in alveolar bone produced with ultrasonic instrumentation, chisel and rotary bur. J Oral Surg 1975;39:536-546.

5. Khambay BS, Walmsley AD. Investigations into the use of an ultrasonic chisel to cut bone. Part 1: Forces applied by clinicians. J Dent 2000;28:31-37.

6. Kerawala CJ, Martin IC, Allan W, Williams ED. The effects of operator technique and bur design on temperature during osseous preparation for osteosynthesis self-tapping screws. Oral Surg Oral Med Oral Pathol Oral Radiol Endod 1999;88:145-150.

7. Fister J, Gross BD. A histologic evaluation of bone response 
to bur cutting with and without water coolant. J Oral Surg 1980;49:105-111.

8. Lavelle C, Wedgwood D. Effect of internal irrigation on frictional heat generated from bone drilling. J Oral Surgery 1980;38:479-503.

9. Yacker MJ, Klein M. The effect of irrigation on osteotomy depth and bur diameter. Int J Oral Maxillofacl Implants 1996; 11:634-638.

10. Eriksson RA, Albrektsson T. The effect of heat on bone regeneration: an experimental study in the rabbit using the bone growth chamber. J Oral Maxillofac Surg 1984;42:705711.

11. Simpson HE. Experimental investigation into the healing of extraction wounds in macacus Rhesus monkeys. J Oral Surg
Anesth Hosp Dent Serv 1960;18:391-399.

12. Pinto JR, Bosco AF, Okamoto T, Guerra JB, Piza IG. Effects of nicotine on the healing of extraction sockets in rats. A histological study. Braz Dent J 2002;13:3-9.

13. Zecchin KG, Pereira MC, Colleta RD, Graner E, Jorge J. Ovariectomy reduces the gelatinolytic activity and expression of matrix metalloproteinases and collagen in rat molar extraction wounds. Calcif Tissue Int 2005;76:136-145.

14. Endo K, Sairyo K, Komatsubara S, Sasa T, Egawa H, Ogawa T, Yonekura D, Murakami R, Yasui N. Cyclooxigenase-2 inhibitor delays fracture healing in rats. Acta Orthop 2005;76:470474 .

Accepted March 9, 2007 